\title{
PERAN TUTORIAL PAI DALAM MENANGKAL PAHAM RADIKAL KEAGAMAAN DI KAMPUS UPI
}

\author{
Dewi Sinta*, Syahidin, Wawan Hermawan \\ Universitas Pendidikan Indonesia (UPI), Indonesia \\ *E-mail:dewisinta2197@gmail.com
}

\begin{abstract}
This research is motivated by the rise of radicalism issues that are vulnerable to spread among students. This radicalism is dangerous, so efforts are needed to counter it. One strategic effort to ward off radicalism is through the role of education. This can be done through the development of the co-curricular, such as Islamic Religious Education (PAI) Tutorial activities which is developed by Universitas Pendidikan Indonesia (UPI). This study aims to know how the role of the PAI Tutorial in counteracting radical religious understanding on the UPI Campus. This research uses a case study design with a qualitative approach. Data collection techniques are carried out by observation, study documentation, interviews, and triangulation. Data analysis techniques are performed by data reduction, data disply, verification and conclusions. Based on the results of the study, it was found that the role of the PAI Tutorial in counteracting radical understanding is to educate UPI Muslim students, by instilling an understanding of tolerant Islam. This is done by formulating and organizing policies and actvities to eliminate the entry of radicalism.
\end{abstract}

Keywords: Radicalism, Islamic Religious Education (PAI), Tutorial, UPI

Abstrak. Penelitian ini dilatarbelakangi oleh mencuatnya isu radikalisme yang rentan tersebar di kalangan mahasiswa. Paham radikal ini berbahaya, sehingga diperlukan adanya upaya untuk menangkalnya. Salah satu upaya strategis untuk menangkal radikalisme tersebut adalah melalui peran pendidikan. Hal ini bisa dilakukan melalui pengembangan kokurikuler, seperti kegiatan Tutorial Pendidikan Agama Islam (PAI) yang dikembangkan oleb Universitas Pendidikan Indonesia (UPI). Penelitian ini bertujuan untuk mengetahui bagaimana peran Tutorial PAI dalam menangkal paham radikal keagamaan di Kampus UPI. Penelitian ini menggunakan desain studi kasus dengan pendekatan kualitatif. Teknike pengumpulan data dilakukan dengan cara observasi, studi dokumentasi, wawancara, dan triangulasi. Teknik analisis data dilakukan dengan reduksi data, disply data, verifikasi dan kesimpulan. Berdasarkan basil penelitian, ditemukan bahwa peran Tutorial PAI dalam menangkal pabam radikal adalab membina mahasiswa Muslim UPI, dengan menanamkan pemahaman tentang Islam yang toleran. Hal ini dilakukan dengan menyusun dan menyelenggarakan kebijakan dan kegiatan untuk mengbilangkan celah masuknya paham radikal.

Kata Kunci: Radikalisme, Pendidikan Agama Islam (PAI), Tutorial, UPI 


\section{PENDAHULUAN}

Radikalisme sampai saat ini masih menjadi isu yang hangat dan heboh diperbincangkan. Menurut Yunus (2017, hal. 77) dunia memang sedang digoncang isu-isu kekerasan yang dianalisis timbul dari gerakan-gerakan radikal.

Sebagai penduduk Indonesia yang beragama Islam, kita tidak boleh memiliki pemahaman Islam yang radikal. Karena hal itu tidak diajarkan oleh Islam, serta berbahaya bagi negara dan Islam itu sendiri. Sementara sangat mencengangkan, hasil penelitian survey yang dilakukan oleh Lembaga Kajian Islam dan Perdamaian (LKIP) Jakarta pada tahun 2010 (Rokhmad, 2012, hal. 81), Abdullah Fadjar dkk. (Munip, 2012, hal. 160) dan hasil survei Badan Nasional Penanggulangan Terorisme (BNPT) (Parma, 2018), menunjukkan bahwa kecenderungan penduduk Indonesia yang mendukung dan memiliki pemahaman radikal itu memang ada saja, di mana yang rentan menjadi korbannya yaitu anak muda, terutama mahasiswa. Oleh karena itu, perlulah dilakukan upaya penangkalannya.

Salah satu elemen yang dapat berperan strategis dalam upaya penang-kalan radikalisme tersebut adalah melalui peran pendidikan, terutama Pendidikan Agama Islam (PAI), karena pembinaan keimanan, ketakwaan, akhlak, kesadaran beragama, termasuk penanaman pemahaman akan radi-kalisme di sekolah dan Perguruan Tinggi memang diamanatkan kepada PAI. Sehingga dalam visi misi dan tujuannya pun diarahkan ke sana. Di mana, dalam upaya menangkal paham radikal melalui PAI tersebut, dapat diupayakan melalui optimalisasi pembelajaran PAI, seperti dengan pengembangannya, evaluasi dan rekontruksi komponen-komponennya, pengaturan kurikulumnya, pengaturan strategi pembelajarannya, dan lain-lain. Sebagaimana hal tersebut senada dengan pandangan menurut Abdussalam dkk. (2018, hal. 2), Supian (2014, hal. 37-39), Novayani (2018, hal. 14), Rahmat (2018, hal. 43), Rosanita (2016, hal. 155), Mufid (2017), Muqoyyidin (2003, hal. 140), dan Syahidin (2001, hal. 2001).

Penyelenggaraan PAI di Universias Pendidikan Indonesia (PAI) menggunakan sistem kredit semester (SKS), yang terdiri dari tiga kegiatan, yaitu: 1) Kegiatan tatap muka di kelas selama 50 menit; 2) Kegiatan kokurikuler (Tugas Terstruktur) selama 60 menit; dan 3) Kegiatan mandiri/ekstakurikuler (UPI, 2017, hal. 32). Tutorial PAI merupakan kegiatan kokurikuler PAI di UPI. Tutorial PAI ini berfungsi sebagai lembaga asistensi mata kuliah PAI, atau dengan kata lain merupakan laboratorium PAI (Supriadi, 2018, hal. 4). Sebagaimana dalam Asyafah dkk.(2018, hal. i) disebutkan bahwa Tutorial PAI sebagai salah satu program unggulan UPI dalam upaya pembinaan akhlak mahasiswa, diharapkan mampu menangkal radikalisme di kalangan mahasiswa UPI.

Berdasarkan hasil pra survey di lapangan, peneliti berasumsi bahwa kegiatan Tutorial PAI di UPI ini di samping dapat menambah wawasan dan pemahaman mahasiswa tentang agama Islam, juga dianggap mampu menangkal pemahaman-pemahaman menyimpang terhadap ajaran Islam. Untuk membuktikan asumsi tersebut, maka perlu diteliti. Atas dasar itu, penelitian ini mengangkat judul "Peran Tutorial PAI dalam Menangkal Paham Radikal Keagamaan di Kampus UPI”.

\section{METODE PENELITIAN}

Dalam penelitian ini, desain penelitian yang digunakan yaitu desain studi kasus (case study). Desain studi kasus adalah bentuk penelitian yang mendalam tentang suatu aspek lingkungan sosial termasuk manusia di dalamnya yang 
dapat dilakukan terhadap seorang individu, segolongan manusia, atau lembaga sosial, serta dapat mengenai perkembangan sesuatu dan gambaran tentang keadaan yang ada (Nasution, 2016, hal. 27). Penelitian ini menggunakan pendekatan kualitatif dengan metode deskriptif. Menurut John W. Creswell (Partilima, 2011, hal. 3), pendekatan kualitatif adalah sebuah proses penyelidikan untuk memahami masalah sosial atau manusia berdasarkan pada penciptaan gambar holistik yang dibentuk dengan kata-kata, melaporkan pandangan informan secara terperinci, dan disusun dengan sebuah latar ilmiah. Serta menggunakan metode deskriptif, karena data yang dikumpulkan adalah berupa kata-kata, gambar dan bukan angka-angka, sehingga harus digambarkan dalam bentuk uraian.

Lokasi penelitian ini bertempat di Islamic Tutorial Center (Masjid AlFurqon) dan Gedung Fakultas Pendidikan Ilmu Pengetahuan Sosial (FPIPS), Universitas Pendidikan Indonesia yang terletak di Jl. Setiabudhi No. 229 Bandung. Pihak yang menjadi partisipan dalam kegiatan penelitian ini adalah mereka yang benar-benar terlibat aktif pada kegiatan Tutorial dan merupakan elemen penting yang diyakini mengetahui informasi-informasi yang dibutuhkan.

Teknik pengumpulan data yang digunakan yaitu observasi, studi dokumentasi, wawancara, dan triangulasi. Oleh karena itu, instrumen penelitian yang disiapkan yaitu berupa kisi-kisi penelitian, pedoman observasi, pedoman studi dokumentasi, dan pedoman wawancara. Observasi yang peneliti lakukan tergolong pada observasi partisipatif jenis partisipasi aktif dan moderat, yang menurut Sugiyono (2017, hal. 227) maksudnya yaitu peneliti ikut melakukan apa yang dilakukan oleh nara sumber, tetapi belum sepenuhnya. Juga terdapat keseimbangan antara peneliti menjadi orang dalam dengan orang luar. Dimana, observasi seperti ini akan memperoleh data yang lebih lengkap, tajam, dan sampai mengetahui pada tingkat makna dari setiap perilaku yang tampak. Dan wawancara dilakukan bertujuan untuk menggali informasi yang mendalam dari informan, juga untuk menkonfirmasi/ memastikan ulang beberapa data yang telah diperoleh melalui observasi dan dokumentasi, agar data yang diperoleh lebih lengkap, valid dan terpercaya. Setelah pengumpulan data, selanjutnya adalah melakukan analisis data dengan cara reduksi data, disply data, lalu verifikasi dan conclusion.

\section{HASIL PENELITIAN DAN PEMBAHASAN}

Tutorial PAI UPI adalah proses pembimbingan yang dilakukan guna meningkatkan kapabilitas dan kualitas pengontrak mata kuliah PAI, dalam menerapkan nilai-nilai Agama Islam yang diterimanya dalam perkuliahan, yang mengarahkan kegiatannya pada aspek pembinaan secara lebih luas, sehingga tidak hanya sebatas berupa mentoring saja (Dok3). Program Tutorial ini berkedudukan sebagai kokurikuler berupa tugas terstruktur dari mata kuliah PAI-MKDU. Sehingga Tutorial PAI di UPI ini telah menjadi sistem tersendiri, yakni menjadi bagian yang tak terpisahkan dari PAI bahkan dari sistem pendidikan di UPI itu sendiri dalam upaya mewujudkan motto kampus religiusnya. Dimana, penyelenggaraan Tutorial PAI di UPI ini selaras dengan teori-teori yang dianjurkan oleh para pemerhati PAI akan pentingnya melakukan upaya pengembangan dan penataan PAI demi mewujudkan visi misi dan tujuan PAI.

Payung hukum Tutorial PAI UPI ini yaitu terdapat dalam Keputusan Rektor UPI Nomor: 8145/H40/KM/2007, Peraturan Rektor UPI Nomor: 
0440/UN40/HK/2016, dan Keputusan Rektor UPI Nomor 3846/UN3846/ KP2018. Struktur orga-nisasi Tutorial ini yakni terdiri dari rektor sebagai penanggung jawab, pembina yang meliputi para wakil rektor, para dekan fakultas, para dirketur kampus daerah, Ketua MKDU, Ketua Harian DKM AlFurqon, dan Koordinator Mata Kuliah PAI/SPAI, kemudian penye-lenggara beserta jajarannya, lalu pengurus dari mahasiswa sebagai pelaksana teknis, dan terakhir Koordinator Tutorial Kampus Daerah. Semua pihak tersebut memiliki tupoksi dan perannya masing-masing (Dok1, Dok3, Dok11, WDP.1, WKPH).

Pelaksanaan Tutorial PAI di UPI terdiri dari dua jenis, yaitu: 1) Reguler, yakni untuk peserta biasa; dan 2) Bina Kader (Binder), yakni untuk peserta pilihan dari perwakilan masing-masing kelasnya, yang memang pembinaannya lebih luas lagi. Dalam satu semester, kegiatan-kegiatan yang biasa dilaksanakan di Tutorial PAI yaitu meliputi rekrutmen tutor, sosialisasi program, diklat tutor, pembinaan pekanan yang berlangsung selama 11 pekan yang terdapat kegiatan inti berupa kuliah duha dan tutoring serta kegiatan olahraga, latihan dasar bela diri, dan salat duha khusus bagi peserta binder, kemudian pembinaan tutor, pengukuhan binder, serta perekapan dan penyerahan nilai, dan pemberian reward tutor (OKD, OKT, OPT, Dok5, Dok6, WKPH, WKBT, WKBP).

Selanjutnya akan dibahas mengenai peran Tutorial PAI dalam menangkal paham radikal. Menurut Kamus Besar Bahasa Indonesia, menangkal artinya menolak (bala, roh halus, penyakit, dan sebagainya); mencegah bencana dan sebagainya. Upaya menangkal radikalisme ini biasa disebut pula dengan deradikalisasi. Menurut KBBI, deradikalisasi adalah praktik mendorong penganut agama atau politik yang radikal untuk mengadopsi pandangan yang lebih moderat. Jadi, istilah menangkal dalam penelitian ini dapat diartikan dengan menolak/ mencegah. Serta peran yang dimaksud dalam penelitian ini yaitu merujuk pada hasil penelusuran menurut KBBI, teori Briddle dan Thomas yang dikutip oleh Sarwono (2015, hal. 224-226), Poerwadarmita (1982, hal. 271), dan menurut Soekanto (2007, hal. 216), yaitu bahwa peran adalah suatu usaha/perilaku yang dilakukan oleh seseorang/subjek yang memegang suatu kedudukan tertentu di masyarakat sebagai pelaksanaan atas hak dan kewajiban yang dimilikinya. Di mana seorang pemilik peran tersebut tentu memiliki peranan tertentu, yaitu bagian/apa yang dapat dilakukan oleh pemegang peran tersebut. Sehingga batasan peran dalam penelitian ini adalah suatu usaha yang dilakukan oleh Tutorial PAI dalam menjalankan hak dan kewajibannya sebagai suatu lembaga pemegang kedudukan berupa penanggung jawab pelaksanaan pem-binaan keagamaan di UPI. Juga batasan peran Tutorial PAI di sini ini adalah peran Tutorial PAI secara lembaga, hasil tangkapan yang dilihat dari peran secara personalnya, dari masing-masing pihak yang terlibat dalam pelaksanaan kegiatan pembinaan di Tutorial PAI, yaitu meliputi peran penyelenggara, pengurus, dan tutornya. Dalam penggolongan peran ini, di sini menggunakan penggolongan peran manajer dalam organisasi menurutHenry Mintzberg (1990). Berikut adalah pemaparannya:

\section{Peran Penyelenggara Tutorial PAI dalam Menangkal Paham Radikal}

Penyelenggara yang dimaksud di sini adalah dosen-dosen yang terlibat dalam penyelenggaraan Tutorial, yakni dari mulai penanggung jawab, para pembina, Ketua Penyelenggara beserta jajarannya, hingga dosen-dosen PAI baik di Kampus Bumi Siliawangi maupun Kampus 
daerah. Sebab Tutorial PAI memang bersangkutan dengan mata kuliah PAI itu sendiri, sehingga seluruh dosen PAI pasti terlibat.

Dalam upaya membawa Tutorial ke arah pengembangan deradikalisasi, secara umum peran penyelenggara adalah: Rektor sebagai penangung jawab beperan sebagai pihak yang paling bertanggung jawab atas penyelenggaraan Tutorial termasuk hal apa saja yang dilakukan oleh Tutorial itu sendiri (OKP). Pembina Tutorial, berperan memberikan bimbingan dalam penyelenggaraan kegiatan Tutorial (Dok3, WDP). Departemen Pendidikan Umum (DPU) FPIPS UPI sendiri berperan menaungi pelaksanaan Tutorial, karena mata kuliah PAI dan SPAI berada di bawah naungan MKDU/DPU. Serta perannya adalah membimbing, meluruskan, mengamati, memonitor, mengevaluasi sejauh mana kegiatan Tutorial berjalan lancar, sejauh mana dilihat dari metode yang digunakannya, kurikulumnya, narasumbernya, peserta sebagai objeknya, dan dari segi lokasinya (Dok3, WKDPU). Sementara Ketua Penyelenggara beserta jajarannya dan Koordinator Tutorial Kampus Daerah adalah dosen-dosen PAI untuk mengkoordinir penyelenggaraan Tutorial beserta penyusunan kebijakannya (OKD, OKP, Dok3, WDP.5, WKPH). Kemudian dosen-dosen PAI baik di Kampus Bumi Siliwangi maupun di Kampus-Kampus Daerah berperan menekankan kepada mahasiswa pengontrak PAI yang diampunya untuk mengikuti Program Tutorial PAI karena hal tersebut wajib sebagai syarat kelulusan PAI. Lalu, beberapa dari dosen PAI bertindak sebagai pengisi materi yang merupakan peran intinya karena untuk menanamkan pemahaman keagamaan yang benar termasuk tentang radikalisme, baik di kegiatan diklat tutor, kuliah duha, dan pembinaan tutor (OKD, OPT, Dok3, WKP, DOK2, WDP).
Namun, pada intinya peran Tim Penyelenggara dalam rangka upaya menangkal paham radikal tersebut, adalah menyusun kebijakan dan menyelenggarakan kebijakan untuk mensiasati tidak terdapatnya celah masuknya paham radikal (OKP, Dok11, Dok2, WDP, WKPH, WKBT). Peran penyelenggara ini dapat digolongkan pada kategori Peran Pengambil Keputusan (Decisional Roles) jenis Enterprener, yang menurut Mintzberg (1990) adalah berperan membuat suatu perubahan dan mengendalikannya untuk kemajuan organisasi, memecahkan masalah dan menghasilkan ide-ide baru serta menerapkannya dalam organisasi, merancang masa depan organisasi, serta membuat proyek-proyek perbaikan dan peningkatan kualitas. Adapun langkahlangkah usaha yang dilakukannya adalah sebagai berikut:

Mula-mula adalah menyusun kebijakan. Ketika akan menyusun ulang kebijakan, langkah pertama adalah dengan melakukan penyamaan persepsi di kalangan dosen terlebih dahulu. Dari mulai penyelenggara, dosen-dosen PAI, DPU, dekan fakultas, direktur kamda, para wakil rektor sampai rektor (WDP.5). Dilakukannya penyamaan persepsi tersebut dapat dikatakan sebagai suatu usaha yang tujuannya tiada lain adalah untuk menghasilkan keputusan bersama dalam memutuskan tindakan apa yang perlu dilakukan. Langkah ini dipandang merupakan langkah yang tepat, karena agar terjalin sinergitas dan keterlibatan antar setiap pihak yang bersangkutan dan saling berpengaruh. Sebagaimana menurut BNPT dan Rokhmad (2012, hal. 80) bahwa keterlibatan berbagai pihak dalam menangani masalah radikalisme dan terorisme adalah sangat diharapkan. Tujuannya adalah untuk mempersempit ruang geraknya, bahkan jika bisa sampai menghilangkannya sama sekali.

Setelah melakukan penyamaan persepsi, langkah selanjutnya adalah 
menyusun program melaui Focus Group Discussion (FGD) Revitalisasi Program Tutorial PAI/SPAI dalam Rangka Menangkal Paham Radikal di UPI, yang dilaksanakan pada Rabu, 11 Juli 2018 bertempat di Hotel Travello Bandung (Dok2, Dok11, WDP, WKPH, WKBT). Menurut KBBI, revitalisasi artinya proses, perbuatan menghidupkan atau menggiatkan kembali. Simpelnya adalah dapat diartikan perbuatan memperbaiki kembali. Syahidin (2001)mengatakan bahwa dalam rangka optimalisasi, nampaknya perlu segera menata kembali dengan kata lain perlu dievaluasi, direvitalisasi, dan direkontruksi komponen-komponennya seperti tujuan, kurikulum, materi, metode, sistem evaluasi, kelembagaan, dosen, dan lainlain. Untuk penataan tersebut diperlukan prinsip-prinsip, strategi dan langkahlangkah pengembangan yang jelas dan akurat sesuai dengan perkembangan masyarakat dan karakteristik PTU-nya sendiri. Berangkat dari teori tersebut, maka revitalisasi yang dilakukan Tutorial PAI ini merupakan upaya yang tepat, karena dalam rangka upaya optimalisasi.Isi dari revitalisasi program Tutorial dalam rangka menangkal paham radikal di UPI ini, yaitu sebagai berikut:

Pertama, pengorganisasian calon tutor. Dalam hal ini menetapkan sistem rekrutmen tutor mengambil dari mahasiswa Ilmu Pendidikan Agama Islam (IPAI) yang tetap diseleksi oleh Ketua Prodi IPAI. Kemudian tutor tambahannya akan mengambil dari pengontrak Seminar Pendidikan Agama Islam (SPAI), dari anak-anak bina kader, pengurus, dan dibuka dari umum apabila kebutuhan tutor belum terpenuhi. Dengan ketentuan calon tutor dari pengontrak SPAI, anak-anak Binder dan umum ini juga tetap akan melalui seleksi pula, yakni dengan mengisi formulir, tes baca Al-Qur'an, tes tulis yang didalamnya berisi pertanyaan-pertanyaan seputar radikalisme, wawancara, dan diwajibkan mengikuti diklat tutor. Dalam wawancara, dites sejauh mana pemahaman agamanya, dan diberi pembekalan untuk tidak memliki pemahaman yang menyimpang. Sehingga di sini dipantau agar benar-benar tidak masuk hal-hal yang tidak diinginkan (Dok2, Dok11, WDP.5, WKPH, WKBT). Keputusan tersebut dipandang memang merupakan ide yang bagus, sebab sebagaimana menurut(Kosasih, Fahrudin, \& Anwar, 2009, hal. 1)bahwa perlu adanya pengaturan serius tentang pola rekrutmen tutornya. Juga menurut (Asyafah, 2019) bahwa salah satu upaya yang harus dilakukan Tutorial dalam upaya menangkal paham radikal adalah dengan menyaring tutor-nya. Namun Udin Supriadi selaku Ketua Penyelenggara mengakui bahwa hal tersebut belum terlaksana secara maksimal di Semester Ganjil tahun 2018 ini, karena berbagai faktor (Dok2). Berdasarkan hasil observasi dan wawancara terhadap ketua biro tutor, semester ini baru terlaksana mengambil dari mahasiswa IPAI saja. Sementara yang mengambil dari pengontrak SPAI dan alumni Binder belum terkondisikan, dikarenakan masih belum dilakukan penyesuaian. Namun walau masih merekrut dari umum, tetapi pada kali ini itu sistemnya benar-benar lebih ketat daripada sebelumnya (OKP, WKBT, WKPH). Melihat pernyataan seperti itu, setidaknya terlihat sudah cukup bagus, hanya saja sebagaimana menurut (Hidayah, 2017, hal. 52-58)untuk kedepannya perlu dievaluasi kembali.

Kedua, revitalisasi materi. Dalam hal ini, menetapkan materi-materi yang berkaitan dengan menangkal radikalisme sebagai materi pokok yang harus ditanamkan di Tutorial. Tema-tema materi hasil revitalisasi tersebut diantaranya saja yaitu: 1) Urgensi dan Kekbijakan Tutorial, 2) Menangkal Radikalisme, 3) Makna Syahadatain bagi reguler Makna Dakwah bagi binder; 4) 
Interaksi dengan Al-Quran; 5) Kesolehan Sosial; 6) Konsep Islam Wasathiyah 7) Konsep Pendidikan Islam, dan Ukhuwah Islamiyah; 8) Iman, Amal Shaleh dan Adab Menuntut Ilmu; 9) Interaksi dengan Al-Quran dan pembinaan kepribadian; 10) Urgensi Dakwah dan Uswatun Hasanah; dan 11) Persatuan Umat dan Ukhiwah Islamiyah (OKD, OPT, Dok2, Dok11, Dok7, WKBT). Melihat tema-tema materi hasil revitalisasi tersebut, dan jika dibandingkan dengan yang sebelum revitalisasi (terdapat pada Dok4 dan hasil pengalaman observasi), terlihat bahwa kali ini memang lebih banyak diselipkan materi-materi tentang yang berkaitan dengan menangkal radikalisme dan Islam rahmatan lil 'alamin, bahkan keseluruhan tema tersebut rata-rata menyinggung halhal yang berkaitan dengan menangkal radikalisme dan Islam rahmatan lil 'alamin tersebut, seperti berisi penanaman ajaran pluralisme, moderat, toleransi, cinta damai, hidup rukun, menghindari saling hujat, dan menghargai perbedaan. Oleh karena itu kegiatan perbaikan kembali kurikulum dengan memuat substansi materi tentang pemahaman radikalisme dan Islam rabmatan lil 'alamin yang dilakukan Tutorial PAI UPI dalam rangka upaya menangkal radikalisme ini adalah merupakan langkah yang tepat. Sebagaimana menurut Rosanita (2016, hal. 155), bahwa diantara upaya untuk menangkal radikalisme adalah perlunya menanamkan pemahaman akan Islam rabmatan lil 'alamin. Juga menurut Rahmat (2018, hal. 59), PAI yang damai, moderat, dan toleran memerlukan substansi materi yang inklusif. Sehingga agar tidak ada lagi yang mengklaim bahwa radikalisme negatif itu dihasilkan oleh mata kuliah maupun mata pelajaran PAI. Serta hal ini selaras pula dengan Suharto \& Assagaf (Suharto \& Assagaf, 2014, hal. 157) bahwa untuk menangkal radikalisme, maka muatan-muatan ajaran Islam menjadi aspek yang harus diperhatikan oleh dosen PAI, seperti perlunya muatan ajaran Islam tentang toleransi, humanisme, dan multikulturalisme. Pemateri-pemateri untuk mengisi pematerian-pemateriannya pun adalah termasuk hal yang direvitalisasi pula. Sekarang, sama sekali tidak diperbolehkan mengundang pemateri dari luar. Hal ini tiada lain adalah untuk menjaga Tutorial dari hal-hal yang tidak diinginkan seperti penyampaian materi yang ngaco, karena yang paham dan mengerti Tutorial adalah dosen-dosen PAI (Dok2, WPD.6, WKPH, WKBT). Hal tersebut menunjukan kehati-hatian dosen-dosen PAI yang cukup tinggi. Selaras dengan pandangan (Asyafah, 2019) bahwa pematerinya pun benarbenar harus diperhatikan.

Ketiga, Manajemen Tutorial. Dalam hal ini disusun kembali terkait manejem pelaksanaan Tutorialnya. Hal ini sejalan dengan (Hidayatulloh, 2013, hal. 168, $188,191)$ bahwa dalam pengorganisasian, maka harus digerakan oleh sesuatu yang dinamis, yang disebut dengan manajemen. Isi dari kebijakan manajemen Tutorial tersebut adalah adanya perubahan pada sistem kuliah duha, penugasan peserta, dan pada proses tutoring-nya, yaitu benar-benar akan diawasi oleh pengurus dan dosen PAI, sehingga jangan sampai ada hal yang mencurigakan. Kemudian ada monitoring tutor. Satu dosen harus memonitoring sepuluh tutor. Rencana program tersebut sejalan dengan Hidayah (2017, hal. 52-58) bahwa pengontrolan memang sangat penting dan dibutuhkan untuk menjamin agar semua rencana dan pelaksanaan kegiatan dapat sesuai dengan tujuan dan mencapai hasil yang lebih baik. Namun Ketua Penyelenggara menyadari bahwa ini belum maksimal di semester ini karena SK-nya telat, yang mudah-mudahan akan ditingkatkan di semester-semester selanjutnya (Dok2). Sebagaimana menurut Marzuki (1997, hal. 94) bahwa 
memanglah tidak gampang untuk merealisasikannya, semoga dapat dievaluasi kembali.

Setelah menyusun kebijakan dan rancangan program-program, selanjutnya adalah menyelenggarakannya. Langkah pertama adalah dengan membenahi dan memperbaiki administrasi. Dalam hal perbaikan administrasi ini, yang dilakukan penyelenggara adalah memastikan secara administrasiuntuk menutup lubang-lubang masuknya pemahaman dan pemikiran radikal (WDP.6). Hal ini selaras dengan apa yang dilakukan oleh pemerintah melalui kurikulum PAI 2013, yang dengan tegas diorientasikan pada pembentukkan pemahaman tentang Islam rahmatan lil 'alamin dan berwawasan kebangsaan sebagai counter terhadap radikalisme beragama (Hamka, 2018, hal. 98). Dengan demikian, pemerintah pun langkah awalnya yaitu bermula dengan memperbaiki administrasi berupa peninjauan dan perbaikan kembali kurikulum. Sehingga upaya menangkal radikalisme melalui pembenahan administrasi untuk memastikan tidak terdapat gejala radikalisme ini dirasa merupakan langkah yang tepat. Lalu, mensosialisasikan kepada pengurus sekaligus men-treatment, mengintruksikan dan mengarahkan pengurus untuk melaksanakan kegiatan Tutorial berdasarkan hasil kebijakan tersebut (OKP, Dok2, WKPH). Hal tersebut memang sudah semestinya dilaksanakan, mengingat pelaksana teknis kegiatannya memanglah dari pengurus. Hal ini sejalan dengan Rokhmad (2012, hal. 80) dan Asyafah (2019) bahwa upaya penangkalan radikalisme tersebut memang memerlukan kerja sama, sinergitas, dan keterlibatan dari berbagai pihak.

Selanjutnya yaitu membina tutor dan peserta dengan menanamkan pemahaman tentang materi-materi hasil revitalisasi yang di dalamnya mengangkat tema-tema berkaitan dengan menangkal radikalisme sebagai materi penting untuk ditanamkan (OKD, OPT, OKP, WDP, WKBT, WDP, WKPH, WKBP). Hal tersebut merupakan langkah yang tepat dan memang semestinya dilaksanakan. Sebab sebagaimana menurut Azyumardi Azra dan Yusuf Al-Qardawi dalam (Baidowi, 2017) serta Rosanita (2016, hal. 155) bahwa sebenarnya perilaku radikal dalam agama adalah ditimbulkan karena pemahaman ajaran agama yang sepotong-sepotong dan tidak secara menyeluruh. Oleh karena itu, penanaman pemahaman agama yang benar memang sangat penting dalam upaya pencegahan radikalisme tersebut. Berdasarkan hasil temuan, ringkasan isi penanaman pemahaman-pemahaman tentang konsep ajaran Islam yang benar, yang ditanamkan oleh dosen-dosen PAI di Tutorial PAI ini baik kepada tutor dan peserta, di antaranya saja sebagai berikut: 1. Singkatnya radikalisme adalah ingin mengganti ideologi negara. Ciricirinya adalah menganggap dirinya paling benar dan menganggap Muslim yang lainnya salah, cenderung mengkafirkan orang lain yang tidak sepaham, mengikuti kajian-kajian tertutup, berbau politik, dan menggunakan cara-cara kekerasan, bersembunyi dalam kata "Jihad", suka memotong-motong ayat $\mathrm{Al}$ Qur'an dan Hadits sehingga menyebarkan ajaran Islam yang salah dan dapat menghancurkan Islam, bisa mencuci otak, biasa menyebut negeri ini sebagai Thagut. Radikalisme bisa disebabkan oleh keadaan ekonomi, sosial dan perbedaan sudut pandang (Dok10.4, WDP.1). Melihat isi pematerian tersebut, poin-poin tersebut memanglah benar adanya, sebagaimana hal ini sangat selaras dengan ciri-ciri dan kriteria Islam radikal menurut Adian Husaini (Laisa, 2014, hal. 6), Yusuf Al-Qarḍawi (Al Hammad, 2018, hal. 22), dan (Munip, 2012, hal. 162). 
2. Fenomena yang seringkali terjadi sekarang ini adalah adanya fanatisme berlebihan, adanya gerakan ekstrimis dan radikal serta beragam pemahaman. Diduga penyebabnya adalah menurunnya semangat mendalami ilmu agama, memahami Al-Qur'an dan Hadits secara tekstual/literal/parsial, serta ekslusif dan liberal dalam dimensi kehidupan. Kita tidak boleh seperti itu, tidak boleh ekstrim, tidak boleh menjelekjelekkan ajaran yang lain, karena Islam tidak ekstrim, Islam tidak radikal, tetapi justru adalah rahmatan lil 'alamin (Dok10.2). Poin-poin isi pematerian tersebut juga selaras dengan tinjauan teori tentang "Pandangan Islam tentang Radikalisme". Yang mana, setelah ditinjau dari beberapa dalil AlQur'an dan Hadits serta penjelasan dari beberapa ahli, memang seperti yang dikemukakan pada pematerian tersebutlah hasilnya.

3. Agar kita terhindar dari perbuatan seperti itu, maka kita harus memperdalam wawasan keagamaan kita, memahami Al-Qur'an dan sunnah secara tekstual dan kontekstual serta menjadi muslim yang moderat dan tidak konservatif/parsial (OKD, Dok10, WDP.5). Hal tersebut selaras dengan pendangan Azyumardi Azra dan Yusuf Al-Qardawi dalam (Baidowi, 2017) serta Rosanita (2016, hal. 155) yang telah dikemukakan juga sebelumnya.

4. Lebih baik kita menjadi Islam yang moderat (pertengahan), tidak boleh ekstrim, baik itu eskrtim kiri maupun kanan. Kita tidak boleh saling menyalahkan, tidak boleh mencela pemahaman lain, tidak boleh mengkafirkan orang lain, karena itu malah menginjak dan merusak prinsip-prinsip Islam. Janganlah kita membuat Islam dan nama muslim yang lain tercemar. Memperjuangkan
Islam itu artinya menjemput pertolongan Allah, tetapi haruslah dengan cara-cara yang Allah izinkan (OKD3, WDP.5). Hal ini selaras dengan yang disampaikan oleh (Mufid, 2017) bahwa perlunya menanamkan pemahaman Islam yang tidak menimbulkan fanatisme golongan dan pembiasaan amal soleh seperti mengajarkan toleransi, cinta damai, hidup rukun, menghindari saling hujat, dan menghargai perbedaan.

Melihat upaya-upaya yang dilakukan oleh dosen-dosen PAI tersebut, nampaknya telah sesuai dengan yang disarankan Rahmat (2018, hal. 61), bahwa PAI yang damai, moderat, dan toleran memerlukan keterbukaan dosen, substansi materi yang inklusif, dan metode yang dialogis-argumentatif. Juga dengan yang disarankan oleh Supian (2014, hal. 37-39) bahwa dosen PAI di PTU diperlukan kerja keras dan waktu yang lebih dalam upaya mengayomi kegiatan keagamaan mahasiswa di kampus untuk dapat menghindari kegiatan-kegiatan keagamaan mahasiswa yang illegal dan tidak terkontrol.

\section{Peran Pengurus Tutorial PAI dalam Menangkal Paham Radikal}

Secara umum pengurus merespon dengan sangat baik terhadap kebijakan penyelenggara yang bermaksud membawa Tutorial ke arah pengembangan deradikalisasi dengan menunjukkan sikap samina wa ațona (OKP, WKPH, WWKP). Hal tersebut memang adalah hal yang seharusnya, karena pengurus itu sendiri merupakan kelompok mahasiswa yang diangkat dan diberi penugasan oleh penyelanggara untuk menjadi pelaksana teknis operasional kegiatan Tutorial (Dok3). Asani mengatakan bahwa respon pengurus adalah bersyukur karena 
mereka jadi mempunyai benteng baru. Sebab melihat keadaan saat itu yang dirasa tegang dan mengagetkan. Yakni sejak adanya isu mahasiswa UPI yang ditangkap di Mako Brimob, ada pihak yang mengaitkan hal tersebut dengan Tutorial, sehingga civitas Tutorial terpengaruhi. Padahal setelah ditelusuruhi, hal tersebut tidak ada kaitannya dengan Tutorial (WWKP). Memang ada segelintir pengurus yang awalnya sempat merasa keheran-heranan, hal tersebut diduga karena mereka yang seperti itu adalah mereka yang tidak hadir saat sosialisasi, yang cenderung masih awam, serta yang cenderung memiliki pemahaman tertentu. Sebab memang masih ada segelintir sekali pengurus yang memiliki keberpihakan terhadap paham tertentu. Tetapi mereka cenderung kurang menunjukkan, kurang aktif dan cenderung tidak membawa pahamnya itu kepada Tutorial, karena telah di-treatment oleh penyelenggara dan ketuanya itu sendiri untuk tidak membawa pahamnya itu ke Tutorial (OKP, WKPH, WWKP). Melihat pernyataan ini, maka hal tersebut menunjukkan telah terciptanya iklim yang bagus,sehingga perlu dipertahankan dan bahkan ditingkatkan.

Secara umum, peran pengurus dalam upaya menangkal paham radikal, yaitu mendukung penyelenggara, menerjemahkan dan melaksanakan kebijakan penyelenggara, serta memfasilitasi pelaksanaan program dengan cara mengatur teknis pelaksanaannya. Hal ini tercermin dalam upaya-upaya yang dilakukan pada setiap prosesnya yang meliputi perencanaan, pengorganisasian, pelaksanaan, dan evaluasi. Dimana, pada kali ini koordinasi dan komunikasi dengan penyelenggaranya semakin lebih ketat dan intens lagi (OKP, WKBP, WKPH, WWKP). Hal ini selaras dengan Munip (2018, hal. 40) bahwa koordinasi yang intens antara pengurus dengan dosen PAI perlu ditingkatkan sehingga dampak negatif mentoring yang berupa ":penggiringan" opini dan pemikiran mahaiswa ke arah pemahaman keagamaan para mentor bisa dihindari. Juga menurut (Katuuk, Mewengkang, \& Kalesaran, 2016, hal. 5) bahwa adanya komunikasi yang baik tentu sangat diperlukan, agar dapat tercipta hubungan yang harmonis/sejalan antar rekan kerja. Dimana, komunikasi ini menjadi kunci utama dalam proses pertukaran informasi antar bagian dalam suatu organisasi. Adapun secara lebih jauhnya mengenai peran pengurus, dapat melihat dari upaya-upaya yang dilakukannya, sebagai berikut:

Ketika akan melaksanakan kegiatan Tutorial hasil revitalisasi, maka langkah pertama adalah dengan menyiapkan perencanaan. Menurut Hidayah (2017, hal. 52-58) perencanaan adalah suatu kegiatan membuat tujuan yang diikuti dengan membuat berbagai rencana untuk mencapai tujuan yang telah ditentukan. Perencanaannya ini dilakukan dengan mengadakan rapat kerja antar semua pengurus juga mengadakan rapat bidang masing-masing untuk menentukan program kerja yang akan dilaksanakan satu semester kedepan, timeline kegiatan, dan strategi pelaksanaan programnya (OKP, Dok5, Dok6, WKPH, WKBT). Kegiatan perencanaan tersebut tentu merupakan hal yang bagus. Karena menurut Hidayah (2017, hal. 5258) perencanaan merupakan hal yang paling mendasar dan dibutuhkan dalam merancang dan membuat suatu kegiatan.

Selanjutnya yaitu melaksanakan pengorganisasian dan pelaksanaan. Pengorganisasian merupakan kegiatan dimana rancangan kegiatan itu diorganisasikan mulai dari pembagian tugas sampai kepada yang lainnya. Sementara pelaksanaan adalah salah satu fungsi manajemen yang berperan penting di dalam mengelola kegiatan h (Hidayah, 2017, hal. 52-58). Pengorganisasian yang dilakukan pengurus ini terlihat berupa mengatur strategi untuk menertibkan 
peserta, tutor, pengurus, dan sarana prasarana demi menunjang kelancaran acara (OKP, OKD, OKT, OPT).Hal tersebut memang sepatutnya dilaksanakan, sebagaimana sejalan dengan (Syahidin, 2001) bahwa dalam rangka upaya penataan, maka diperlukan strategi-strategi yang jelas. Sementara pada kegiatan pelaksanaan, terlihat berupa pelaksanaan/tindakan nyata atas strategi-strategi yang telah dibuat untuk berupaya mengatur, mengondisikan, dan menertibkan SDM demi memastikan lancarnya keberlangsungan acara (OKP, OKD, OKT, OP'T). Adapun secara lebih jelasnya adalah sebagai berikut:

\section{Pengelolaan Tutor}

Dalam melaksanakan rekrutmen tutor, pengurus banyak berkoordinasi dengan penyelenggara dan telah melaksanakan sesuai dengan arahan dari penyelenggara. Kali ini masih membuka untuk umum dikarenakan keperluan tutor belum terpenuhi akibat belum dapat terkondisikannya pengelolaan tutor dari pengontrak SPAI dan alumni Binder. Namun walau masih dibuka untuk umum, tetapi seleksinya semakin ketat lagi. Masih dalam rangka rekrutmen tutor, pada pelaksanaan diklat tutor, pengurus juga telah melaksanakan sesuai intruksi dari penyelenggara bahwa ketentuannya seluruh calon tutor harus mengikuti diklat tutor dan yang tidak hadir diklat tutor maka tidak diluluskan untuk menutor (OKP, WKBT, WKPH). Hal ini selaras dengan apa yang disarankan oleh (Kosasih, Fahrudin, \& Anwar, 2009, hal. 1) bahwa perlu adanya pengaturan serius tentang pola rekrutmen. Juga selaras dengan yang disarankan (Asyafah, 2019) bahwa harus ada penyaringan tutor. Hanya saja tentu perlu ditingkatkan kembali.

Selanjutnya hal-hal lainnya berkaitan dengan peran pengurus dalam pengelolaan tutor dalam upaya menangkal paham radikal adalah: 1)
Memfasilitasi pelaksanaan kegiatan pembinaan tutor berdasarkan arahan dari penyelenggara; 2) Mengelola, memberi informasi, dan memberi intruksi kepada tutor berdasarkan intruksi dari penyelenggara; 3) Mengatur, mengondisikan, dan mengarahkan tutor menunaikan kewajibannya untuk menutor dan mengikuti pembinaan tutor dengan baik; 4) Memberikan pedoman bagi tutor, meliputi sistem tugas dan penilaian peserta, dan suplemen materi tutoring dari penyelenggra yang meliputi Menangkal Radikalisme, Makna dan Implementasi Syahadatain, Uswah Hasanah, Ukhuwah Islamiyyah, Interaksi dengan Al-Qur'an, Adab Mencari Ilmu, Pembinaan Kepribadian Muslim; dan 5) Memonitoring tutor, terutama ketika kegiatan tutoring (OPT, OKT, WPMT). Melihat tema-tema materi tutoring tersebut, terlihat bahwa tema-temanya adalah berisi tentang ajaran Islam rahmatan lil'alamin, yang mana hal ini sangat penting dalam upaya menangkal paham radikal. Sebagaimana pendapat (Rosanita, 2016, hal. 155) bahwa guru yang mengajarkan agama perlu menanamkan pemahaman akan Islam rahmatan lil 'alamin. Kemudian berkaitan dengan monitoring tutor, hal tersebut tentu sangat bagus, karena dalam rangka pengendalian, yang menurut (Hidayah, 2017, hal. 52-58) pengendalian merupakan salah satu fungsi manajemen yang dibutuhkan untuk menjamin agar semua keputusan rencana dan pelaksanaan kegiatan mencapai suatu tujuan dengan hasil yang lebih baik.

\section{Pengelolaan Peserta}

Peran pengurus dalam hal pengelolaan peserta dalam rangka menangkal paham radikal adalah: Pertama, mengadakan perubahan pada ketentuan tugas-tugas bagi peserta atas hasil koordinasi dengan penyelenggara. Perubahannya yaitu teletak pada: a) Sekarang menjadi diwajibkannya 
membuat resume pematerian kuliah duha setiap pekannya (OKD, WKBT). Hal ini tentu bagus, karena agar memacu peserta untuk memperhatikan; b) Mengubah tugas kajian ayat menjadi presentasi kelompok dengan ketentuan mempresentasikan 3 resume kuliah duha tentang tema Menangkal Radikalisme, Makna Syahadatain (bagi reguler) Makna dan Urgensi dakwah (bagi Binder), dan Interaksi dengan Al-Qur'an (OKT, WKBT). Diadakannya tugas tersebut dapat dipandang bagus, karena agar dapat memastikan supaya terjadinya diskusi kelompok terutama tentang tema menangkal radikalisme, yang sekaligus bertujuan me-review agar dapat lebih menguatkan ingatan dan pemahaman peserta tentang tema tersebut. Kedua, melaksanakan perubahan sistem kuliah duha atas koordinasi dengan penyelenggara. Perubahannya yaitu: 1) Pematerian menjadi lebih diperbanyak sesi diskusinya yaitu 20 menit pematerian dan 40 menit tanya jawab, karena untuk menghindari kejenuhan peserta, kemudian dibuat jadwal jurusan yang bertanya. Alhasil kuliah duha yang sekarang itu terlihat lebih efektif dan pesertanya terlihat lebih aktif; 2) Pembacaan Al-Matsurat diganti dengan tilawah saja. Yang mana, tujuan digantinya żikir Al-Matsurat dengan tilawah ini adalah untuk lebih berhatihati, sebab Al-Matsurat seringkali diidentikkan dengan ciri khas yang biasa dipakai oleh golongan-golongan tertentu (OKD, WKPH, WKBT).Ketiga, pengurus selalu mengatur, mengondisikan, dan memantau peserta bagaimana agar peserta dapat mengikutinya dengan baik, terutama saat pematerian kuliah duha. Sehingga pengurus berperan membantu penyelenggara agar peserta dapat menyimak pematerian dengan baik, supaya hasil yang diperolehnya juga baik (OKD, OKT). Melihat upaya-upaya dalam pengelolaan tutor dan peserta tersebut, maka hal itu dirasa selaras dengan pandangan (Asyafah, 2019) bahwa salah satu upaya yang harus dilakukan agar dapat menangkal paham radikal dalam aturannya perlu dibuat rambu-rambu bagaimana supaya tidak masuk celah-celah radikalisme yang negatif.

Kemudian, pengurus rutin melakukan evalusi. Evaluasi sangat dibutuhkan dalam hal memonitoring kembali terhadap kegiatan yang dilaksanakan (Hidayah, 2017, hal. 52-58). Berangkat dari teori tersebut, maka Tutorial terbilang telah melaksanakan anjuran tersebut dengan terorganisir. Yaitu karena Tutorial rutin mengadakan evaluasi setiap pekan, setiap selepas melaksanakan acara besar, setiap akhir semester, dan dibantu oleh bidang Litbang yang bertugas memonitoring dan mengevaluasi keaktifan dan kinerja pengurus, serta melakukan riset pelayanan Tutorial kepada para tutor dan peserta, termasuk meneliti tingkat keberhasilan program deradikalisasi tersebut (OKP, WKPH, WKBT, WKBP, Dok12).

Selain poin-poin bentuk usaha yang telah disebutkan di atas, Pengurus Tutorial juga sempat mengadakan kajian yang mengundang perwakilan para aktifis organisasi keIslaman yang ada di UPI, yang di dalamnya ditanamkan pemahaman tentang menangkal radikalisme pula, yang harapannya dapat membangun sinergitas untuk menyamakan persepsi tentang radikalisme dan untuk mengarahkan mereka agar membawa anggota pada pemahaman agama yang benar, namun intensitasnya masih sedikit (OKO). Hal ini selaras dengan pandangan Abas Asyafah (2019) bahwa pentinglah adanya sinergitas antara Tutorial dengan UKM-UKM, karena bisa jadi di Tutorial ditanamkan upaya menangkal radikalisme, tetapi di UKM-UKM tertentu justru malah dipupuk. Oleh karena itu, sinergitas 
dengan UKM-UKM ini adalah hal yang bagus dan perlu ditingkatkan kembali.

Dengan melihat peran-peran pengurus tadi, maka peran pengurus tersebut dapat digolongkan pada kategori: a) Peran Informasional (Informational Roles) jenis Pemantau (Monitor), yaitu berperan sebagai pencari informasi yang berkaitan dengan organisasi, memantau tim yang dipimpinnya; b) Peran Informasional (Informational Roles) jenis Penyebar Informasi (Disseminator), yaitu berperan menyebarkan dan mengkomunikasikan informasi tersebut ke anggota timnya ataupun yang lainnya; c) Peran Antarpribadi (Interpersonal Roles) jenis Penghubung (Liaison), yaitu membangun dan menjaga komunikasi dengan internal maupun eksternal organisasi; dan d) Peran Pengambil Keputusan (Decisional Roles) jenis Pembagi Sumber Daya (Resource Allocator), yaitu berperan sebagai pembagi sumber daya (Mintzberg, 1990).

\section{Peran Tutor Tutorial PAI dalam Menangkal Paham Radikal}

Tutor merupakan ujung tombak dari kegiatan Tutorial PAI, sehingga menjadi hal yang sangat penting. Karena mereka adalah kepanjangan dari dosen, membantu membina pada kegiatan tutoring, jika tidak ada tutor maka kegiatan mentoring tidak akan bisa berjalan (WKBT). Ia menanamkan pemahaman-pemahaman yang telah didapatnya kepada tutee-nya dalam lingkaran kelompok kecil yang notabenenya dapat lebih kondusif dan efektif (Dok12, WWKP). Dengan demikian, Tutorial akan memberikan pengaruh yang sangat besar tatkala tutor berperan sebagai fasilitator yang baik dari pada sebatas pengajar (Dok3). Tutor adalah mahasiswa UPI yang telah diseleksi oleh dosen dan ditugaskan secara sah untuk membimbing kelompok Tutorial PAI pada kegiatan tutoring.
Dimana tutoring adalah sebuah model pembinaan yang dilakukan secara efektif dalam sebuah kelompok kecil (Dok3). Senada dengan Falah (Falah, 2014, hal. 179) bahwa Tutorial adalah bimbingan pembelajaran dalam bentuk pemberian arahan, bantuan, petunjuk, dan motivasi agar siswa belajar secara efektif dan efisien. Sehingga benarlah jika tutor dikatakan sebagai ujung tombak dari kegiatan Tutorial itu sendiri. Karena peserta akan lebih mudah menangkap ilmu ketika kegiatan tutoring, akibat suasana belajarnya yang dapat lebih kondusif dan efektif. Pada kegiatan kuliah duha, masih memungkinkan sekali jika banyak peserta yang tidak menyimak dengan baik sehingga tidak banyak memperoleh ilmu. Tetapi pada kegiatan tutoring, maka kemungkinan untuk tidak memperhatikannya akan lebih kecil. Ketika tutor tidak hadir dan seringkali beralangan hadir, maka itu berdampak negatif pula terhadap peserta, yaitu dapat membuat peserta merasa badmood, kecewa, dan memberikan respon yang kurang baik terhadap Tutorial itu sendiri.

Sehingga, oleh karena tutor merupakan salah satu komponen penting dalam pelaksanaan Tutorial PAI, sebab tutor turut membimbing peserta, yang sosoknya sangat berpengaruh terhadap idealisme yang akan dibentuk tutee-nya itu, maka tutor juga adalah termasuk yang di-treatment, dibina, dandiperhatikan betul-betul oleh para penyelenggara, yaitu dengan diharuskannya mengikuti kegiatan diklat tutor dan pembinaan tutor (OPT, Dok2, Dok11, WKPH, WKBT).Hal tersebut memanglah sangat bagus dan perlu untuk dilakukan. Namun agar mendapat hasil yang bagus, maka sebagaimana menurut (Kosasih, Fahrudin, \& Anwar, 2009, hal. 1) perlu adanya pengaturan serius tentang pembinaan para tutornya. Karena memang disayangkan, tutor yang hadir pada kegiatan Bintor seringkali hanya sedikit (OP'T). 
Kemudian, mayoritas tutor merespon dengan baik berkaitan dengan kebijakan Tutorial yang baru, yang bermaksud membawa Tutorial ke arah pengembangan deradikalisasi, karena salah satunya dari proses seleksi tutornya itu sendiri memang dilaksankan dengan sangat ketat (OPT, OKT, WKPH, WWKP, WPMT). Hal tersebut tentu merupakan kabar gembira bagi para penyelenggara dan pengurus sekalian. Menurut hasil riset Litbang Tutorial (2018), ada sekitar dua-tiga orang yang terindikasi menyatakan respon/hasil yang kurang baik, yakni yang menyatakan belum memahami pematerian dari dosen tentang menangkal radikalisme, belum menyatakan setuju terhadap tidak diperbolehkannya memiliki paham radikal yang negatif, dan belum menyatakan setuju bahwa kita harus memiliki pemahaman agama yang moderat (Dok12). Hasil observasi dan wawancara tehadap Wakil Ketua Pengurus menyatakan bahwa mereka yang seperti itu adalah mereka yang jarang mengikuti kegiatan pembinaan tutor atau ketika hadir ia kurang memperhatikan dengan baik (OPT, OKT, WWKP). Oleh karena itu, ini merupakan PR bagi para penyelenggara dan pengurus agar tidak bosan-bosannya untuk mencari solusi atas permasalahan klasik tentang tutor tersebut.

Peran tutor pada kegiatan Tutorial adalah: 1) Menyampaikan kembali informasi yang diberikan pengurus kepada peserta seperti tentang kebijakan dan tugas-tugas yang harus peserta penuhi. 2) Melaksanakan pembelajaran dan menyampaikan materi ke-Islaman sesuai silabus yang ditetapkan penyelenggara, 3) Me-review, memperdalam, dan men-sharing-kan kembali pematerian yang disampaikan oleh dosen di kuliah duha, 4) Menjadi moderator dalam diskusi kelompok, menjadi tempat diskusi, tempat curhat, dan tempat sharing(OKT, WPMT, WWKP, WKBT).
Jika dikaitkan dengan teori peran guru dalam diskusi kelompok terbimbing model tutorial/mentoring menurut (Falah, 2014, hal. 180) yang mengatakan bahwa umumnya adalah sebagai fasilitator, moderator, dan evaluator. Tetapi, dalam pembelajaran tutorial ini, menekankan peran siswa lebih dominan daripada guru. 1) Sebagai fasilitator, berperan dalam menyam-paikan materi, juga sebagai pengamat proses, dan teman diskusi 2) Sebagai moderator, berperan menjadi perantara kegiatan berinteraksi dan berkomynikasi; 3) Sebagai evaluator, berperan melakukan penilaian untuk mengetahui apakah materi yang diajarkan sudah dikuasai oleh siswa atau belum; maka peran tutor pada kegiatan Tutorial PAI terbilang selaras dengan teori tersebut.

Berdasarkan hasil penelitian berkaitan dengan peran tutor dalam menangkal paham radikal, tutor memang berperan turut memberi pemahaman tentang menangkal radikalisme kepada tutee-nya, dengan cara mengulas pematerian kuliah duha dari dosen serta membuka diskusi dan sharing, sehingga dapat lebih menguatkan ingatan tutee-nya. Dimana, pada proses diskusi kelompok tersebut, tutor dapat memberikan kemampuan kepada peserta untuk dapat menganalisis paham radikal, dan dapat menanamkan sikap menolak terhadap paham radikal, serta dapat mengarahkan peserta untuk berpemahaman moderat (OKT, WDP.1, WKBT, WKPH, WWKP). Jika dikaitkan dengan teori (Humaizi, Harahap, Hanafiah, \& Sinaga, 2017, hal. 22) yang mengatakan bahwa peran kelompok diskusi mahasiswa ini diperlukan untuk menangkal radikalisme dan paham terorisme di lingkungan perguruan tinggi dengan cara memperhatikan konten materi dan pembahasan dari diskusi yang diikuti, maka hal tersebut selaras dengan apa yang telah Tutorial PAI UPI coba lakukan. 
Hal tersebut juga terlihat dari hasil riset yang dilakukan oleh Litbang Tutorial tahun 2018 bahwa dari sebanyak 43 responden, ketika ditanya "Selama menutor, saya turut menanamkan pemahaman tentang menangkal radikalisme kepada tutee dalam rangka deradikalisasi", hasilnya menyatakan 38 orang menjawab "Ya" dan 5 orang menjawab "Tidak". Hal itu menunjukkan bahwa mayoritas tutor memang berperan menanamkan pemahaman tentang menangkal radikalisme kepada tutee-nya (Dok12). Dengan demikian, dapat terlihat bahwa tutor telah cukup berperan dalam upaya menangkal paham radikal di kalangan peserta Tutorial PAI. Walaupun memang terlihat masih terdapat kekurangan dari segi cukup banyaknya tutor yang terlihat kurang komitmen dan kurang amanah dalam mengemban kewajibannya untuk giat menutor terlebih untuk giat mengikuti kegiatan pembinaan tutor (OKT, OPT), yang tentu hal tersebut berpengaruh terhadap tingkat keberhasilan program yang dicapai. Untuk menyikapi hal tersebut, maka penyelenggara dan pengurus tidak boleh bosan untuk melakukan evaluasi kembali. Sebagaimana menurut Alba ( 2011 , hal. 1031-1032) bahwa kegiatan mentoring perlu dievaluasi agar terlihat dimana keberhasilan dan kekurangan dari upaya yang dilakukan.

Melihat peran tutor sebagai fasilitator, moderator, dan evaluator tersebut, maka peran tersebut dapat digolongkan pada kategori Peran Informasional (Informational Roles) jenis Juru Bicara (Spokesperson). Yang menurut (Mintzberg, 1990) artinya adalah berperan meneruskan informasi ke pihak luar.

\section{KESIMPULAN}

Berdasarkan hasil penelitian, dapat diketahui bahwa secara umum peran
Tutorial PAI dalam menangkal paham radikal keagamaan di Kampus UPI adalah membina mahasiswa muslim UPI pada kegiatan Tutorial PAI dengan menanamkan pemahaman tentang materi-materi yang berkaitan dengan menangkal radikalisme seperti tentang Islam toleran dan Islam rabmatan lil 'alamin. Dimana, seluruh mahasiswa muslim UPI pasti akan mendapat pembinaan tersebut, dikarenakan akan mendapat gilirannya masing-masing dalam hal diwajibkannya mengikuti Program Tutorial tersebut.

Implikasi dari penelitian ini adalah menunjukan bahwa upaya penangkalan radikalisme melalui peran lembaga pendidikan ini menjadi penting untuk dilakukan, mengingat sangat strategisnya peran pendidikan tersebut, terutama Pendidikan Agama Islam. Yang mana melalui PAI tersebut, dapat ditanamkan pemahaman-pemahaman agama yang benar untuk mencegah pemahamahan agama yang parsial yang dapat memicu penyebab radikalisme tersebut. Sehingga PAI untuk dapat menghadapi berbagai permasalahan dan tantangan termasuk tantangan berupa radikalisme tersebut, maka diperlukan upaya pengembangan dan penataan kembali terhadap komponen-komponen yang berkaitannya.

Rekomendasi yang ditawarkan dari hasil penelitian ini adalah bagi perguruan tinggi lainnya terutama PTU yang menyelenggarakan Tutorial/ Mentoring PAI pula, semoga dapat menjadi referensi untuk dapat mengembangkan hal yang sama/yang lebih bagus dari yang telah dilakukan oleh Tutorial PAI UPI ini. Juga bagi yang belum melakukan pengembangan PAI melalui kokurikuler, semoga dapat menjadi bahan renungan dan sumber inspirasi untuk tergerak melakukan pengembangan PAI tersebut, walaupun sesuai dengan kemampuan dan caranya masing-masing. Serta termasuk bagi 
sekolah-sekolah dari tingkat SD hingga SMA diharapkan mampu mengembangkan pembelajarannya terutama pada pelajaran agama ke arah deradikalisasi minimal dalam kegiatan intrakurikulernya terlebih dahulu.

\section{REFERENSI}

Adussalam, A., Syahidin, Hadyanto, A., Hanafi, Y., Suaeb, D., Suryana, T., et al. (2018). Panduan Pelaksanaan Bimbingan Teknis Dosen MKWU Pendidikan Agama Islam tahun 2018. Ristekdikti.

Al Hammad, A. M. (2018). Radikalisme di Kalangan Mahasiswa Surabaya (Studi Kasus Kreteria Radikalisme Menurut Yusuf alQardhawi).(Skripsi). Surabaya: Jurusan Aqidah dan Filsafat Islam Fakultas Ushuluddin dan Filsafat Universitas Islam Negeri Sunan Ampel.

Alba, C. ( 2011 ). Studi Aktivitas Masjid Kampus dan Peminaan Iman dan Taqwa bagi Mahasiswa di Perguruan Tinggi Umum. Jurnal Sosioteknologi Edisi 22 .

Asyafah, A. (2019, Januari 7). Pandangan Dosen PAI tentang Radikalisme dan Peran Tutorial PAI dalam Menangkal Radikalisme. Sinta, Interviewer)

Asyafah, A., Syahidin, Abdussalam, A., Rahmat, M., Fahrudin, Suryana, T., et al. (2018). Laporan Hasil Revitalisasi Forum Group Discussion (FGD) Revitalisasi Program Tutorial PAI/SPAI dalam Rangka Menangkal Paham Radikal di Universitas Pendidikan Indonesia. Bandung.

Badan Nasional Penanggulangan Terorisme (BNPT). (Tanpa Tahun). Strategi Menghadapi Paham Radikalisme Terorisme-ISIS.
Baidowi. (2017). Islam Tidak Radikalisme dan Terorisme. Seminar Nasional Hukum UNS, 3(1), 197-218.

Falah, I. F. (2014). Model Pembelajaran Tutorial Sebaya: Telaah Teoretik. Jurnal Pendidikan Agama IslamTa'lim, 12(2), 175-186.

Hamka. (2018). Dinamika Kebijakan Pendidikan Agama Islam di Perguruan Tinggi Umum. Scolae: Journal of Pedagogy, 1(1), 92-100.

Hidayah, F. (2017). Peran Manajemen Dakwah dalam Kegiatan Keagamaan di Pondok Pesantren Nabdatul Ulum 2 Bonto Parang Kabupaten Jenepento.(Skripsi).Makasar:

Fakultas Dakwah dan Komunikasi UIN Alauddin.

Hidayatulloh, F. S. (2013). Manajemen Pendidikan Agama Islam di Perguruan Tinggi Umum (Studi Kasus di Institut Pertanian Bogor). Manajemen Pendidikan Agama, XXVIII(2), 185-202.

Humaizi, Harahap, R. H., Hanafiah, R., \& Sinaga, R. S. (2017). Pendayagunaan Kelompok Diskusi Mahasiswa dalam Menangkal Paham Radikal dan Paham Terorisme di Lingkungan Perguruan inggi. Jusnal Ilmiah Kajian Lokal dan Pembangunan, 4(2), 18-23.

Katuuk, O. M., Mewengkang, N., \& Kalesaran, E. (2016). Peran Komunikasi Organisasi dalam Meningkatkan Eksistensi Sanggar Seni Vox Angelica. e-journal "Acta Diurna", V(5).

Kosasih, A., Fahrudin, \& Anwar, S. (2009). Pengembangan Model Pembelajaran PAI melalui Pembinaan Keagamaan Berbasis Tutorial menuju Terciptanya Kampus UPI Religius. Jurnal Penelitian, 9(1), 1-15.

Laisa. (2014). Islam dan Radikalisme. Islamuna, 1(1). 
Marzuki. (1997). Pendidikan Agama Islam di Perguruan Tinggi Umum dan Pemberdayaan Masyarakat Indonesia. Cakrawala Pendidikan(1), 93-101.

Mintzberg, H. (1990). Mintzberg on Management: Inside our Strange World of Organization.

Mufid, M. (2017). Peranan Guru PAI dalam Upaya Menangkal Radikalisme pada Peserta Didik di SMAN

Yogyakarta.(Skripsi).Yogyakarta: Jurusan Ilmu Pendidikan Agama Islam Fakultas Ilmu Tarbiyah dan Keguruan Universitas Islam Negeri Sunan Kalijaga.

Munip, A. (2012). Menangkal Radikalisme Agama di Sekolah. Jurnal Pendidikan Islam, I(2).

Munip, A. (2018). Perkuliahan Pendidikan Agama Islam di Perguruan Tinggi Negeri (Sebuah Catatan Lapangan). Jurnal Pendidikan Agama Islam, V(1), 1542.

Muqoyyidin, A. W. (2003). Membangun Kesadaran Inklusif- Multikultural untuk Deradikalisasi Pendidikan Islam. Jurnal Pendidikan Islam, $I I(1)$.

Nasution, S. (2016). Metode Research (Penelitian Ilmiah). Jakarta: Bumi Aksara.

Novayani, I. (2018). Studi Kebijakan Pengembangan Pendidikan Agama Islam di Sekolah dan di Perguruan Tinggi Umum (PTU). Jurnal At-Tadbir STAI Darul Kamal NW Kembang Kerang, I(2).

Parma, A. (2018, Februari 13). Retrieved Oktober 4, 2018, from http://www.pikiran-

rakyat.com/nasional/2018/02/1

3/mahasiswa-target-rekrutmengerakan-radikal-419430

Partilima, H. (2011). Metode Penelitian Kualitatif. Bandung: Penerbit Alfabeta.
Poerwadarmita, W. (1982). Kamus Umum Babasa Indonesia. Jakarta: Balai Pustaka.

Rahmat, M. (2018). Model Perkuliahan Pendidikan Agama Islam Yang Damai, Moderat, dan Toleran. Nadwa: Jurnal Pendidikan Islam, 12(1), 39-64.

Rokhmad, A. (2012). Radikalisme Islam dan Deradikalisasi Paham Radikal. Walisongo, 20(1), 79-114.

Rosanita, D. (2016). Persepsi Guru PAI tentang Radikalisme Agama (Studi Multisitus si Sekolah Menengah Atas Negeri 1, Sekolah Menengah Kejuruan Negeri 1, dan Madrasah Aliyah Negeri 1 Kota Mojokerto.(Tesis). Malang: Program Studi Magister Pendidikan Agama Islam Sekolah Pasca Sarjana Universitas Islam Negeri Maulana Malik Ibrahim.

Sarwono, S. W. (2015). Teori-Teori Psikologi Sosial. Jakarta: PT Raja Grafindo Persada.

Soekanto, S. (2007). Sosiologi Suatu Pengantar. Jakarta: PT Raja Grafindo Persada.

Sugiyono. (2017). Metode Penelitian Kuantitatif, Kualitatif, dan R\&D . Bandung: Penerbit Alfabeta.

Suharto, T., \& Assagaf, J. (2014). Membendung Arus Paham Keagamaan Radikal di Kalangan Mahasiswa PTKIN. Al-Tabrir, 14(1), 157-180.

Supian. (2014). Ekslusivitas Kegiatan Keagamaan Mahasiswa (ROHIS) di PTU: Bibit-Bibit Radikalisme? 18-40.

Supian, \& Rahman. (2016). Strategi dan Kebijakan dalam Menetralisir Ekslusivitas Kegiatan Keagamaan Mahasiswa (ROHIS) di PTU.

Supriadi, U. (2018). Buku Peserta Tutorial PAI DPU Universitas Pendidikan Indonesia. Bandung: Value Press, DPU. 
Syahidin. (2001). Pengembangan Pendidikan Agama Islam Di Perguruan Tinggi

Umum (Studi Kasus di IKIP

Bandung Tabun 1966 -1999).

Jakarta: Institut Agama Islam

Negeri Syarif Hidayatullah.

Terorisme, B. N. (n.d.). Strategi Menghadapi Paham Radikalisme Terorisme - ISIS.

UPI. (2017). Peraturan Rektor Universitas Pendidikan indonesia Nomor6448/UN40/HK/2017 tentang Pedoman Penyelenggaraan Pendidikan UPI Tabun 2017.

Sarwono, S. Wirawan (2015). Teori-Teori Psikologi Sosial. Jakarta: PT Raja Grafindo Persada.

Yunus, A. F. (2017). Radikalisme, Liberalisme dan Terorisme: Pengaruhnya Terhadap Agama Islam. Jurnal Studi Al-Qur'an, 13(1). 